\title{
CONCEPT OF DIVIDEND IRRELEVANCE THEORY
}

\author{
Sanjay Shrestha
}

Department of Management, TU, Thakur Ram Multiple Camapus, Birgunj, Nepal

\begin{abstract}
This Article states that dividend policy does not affect the value of the firm. Their argument is that stack holder's wealth is unaffected whether corporate profits are distributed or retained in the business. Their reasoning is that under an efficient market condition, a firm's value is determined by its potential earning power and it does not affect the decision on how profits are to be split between dividends and retained earning. Therefore, as per M-M theory a firm's value is independent of dividend policy.
\end{abstract}

\section{Keywords}

Dividend policy; Market value per share; Investment Policy; Cost of equity; No. of New shares

\section{Introduction}

The major argument indicating that dividends are irrelevance was first propounded by Franco Modigliani and Merton miller in 1961. It is popularly known as M-M Approach. This theory states that dividend policy does not affect the value of the firm i. e. dividend policy has no effect on the share price of the firm. They argued that the value of the firm depends on the firm's earning which depend on its investment policy. Therefore, as per M-M theory, a firm's value is independent of dividend policy.

According to M-M, dividend policy of a firm is irrelevant, as it does not affect the wealth of the share holders. They argued that the value of the firm depends on the earning power of the firm's assets or its investment policy. Thus, when the investment policy is given, dividend decision-splitting the earnings into packages of retention and dividends do not influence the value of equity shares. In other words, the division of earnings between dividend and retained earning is irrelevant from share holders view point.

In general, the argument supporting the irrelevance of dividend valuation is that dividend policy of the firm is a part of its financing decisions. As a part of the financing decision of the firm, the dividend policy of the firm is a residual decision and dividends are passive residual.

\section{Assumptions}

The M-M approach of irrelevance dividend is base on the following assumptions: 
1. The firm operates in perfect capital market where all investors are rational. Information is freely available to all investors. Securities are infinitely divisible and no investor is large enough to influence the market price of securities.

2. There are no floatation costs. The securities can be purchased and sold without payment of any commission or brokerage, etc.

3. There does not exist taxes. Alternatively, there is no tax differential between income on dividend and capital gain.

4. The firm has a definite investment policy, which is not subject to change.

5. There is no uncertainty a to future investment and profit of the firm. Thus, investors are able to predict future prices and dividends with certainty.

When a firm pays its earnings as dividends, it will have to approach market for procuring funds to meet a given investment program. Acquisition of additional capital will dilute the existing share which results in drop of share value. Thus, what the stock holder gain in cash dividend, they loose in decreased share values. The market price before and after payment o dividend would be identical and hence the share holders would be indifferent between dividend and retention of earnings. This suggests that dividend decision is irrelevant.

\section{Mathematical formulation}

M-M provides the proof in support of their argument in the following mathematical formulation to prove irrelevance of dividend decision.

\section{Step-1}

The market price of a share of the firm in the beginning of the period is equal to present value of dividend paid at the end of period plus the market price of the share at the end of the period. This can be expressed as below.

Where, $\begin{array}{ll}\mathrm{P}_{\mathrm{o}}= & \mathrm{D}_{1}+\mathrm{P}_{1} \\ 1+\mathrm{K}_{\mathrm{e}}\end{array}$

$\mathrm{P}_{\mathrm{o}}=$ Current market price of share

$\mathrm{K}_{\mathrm{e}}=$ Cost of equity capital (assumed constant)

$\mathrm{D}_{1}=$ The dividend per share to be received at the end of period one

$\mathrm{P}_{1}=$ The market price of share at the end of the period one

\section{Step-2}

Multiplying both side of equation (1) by the number of share outstanding (n) to obtain the total value of the firm if number of no new financing exists.

$$
\mathrm{nP}_{\mathrm{o}}=\begin{gathered}
\mathrm{n}\left(\mathrm{D}_{1}+\mathrm{P}_{1)}\right. \\
1+\mathrm{K}_{\mathrm{e}}
\end{gathered}
$$

Where,

$\mathrm{n}=$ number of shares outstanding

\section{step-3}

If the firm issues (sells) number of new shares (m) to finance the new investment needs of the fund at a price of $P_{1}$, the value of firm at time zero will be,

$$
\begin{gathered}
n P_{o}=n_{1}+P_{1}(n+m)-m P_{1} \\
1+K_{e}
\end{gathered}
$$

Where,

$\mathrm{M}=$ number of new equity share issued at the end of period

Thus, the total value of the firm as per is equal to capitalized value of the dividend to be received during the period plus the value of the number of shares outstanding at the end of period less the value of the newly issued shares.

\section{Step-4}

If the investment proposal of a firm in given period of time can be financed either of retained earning or the issuance of new 
share or both. Thus, the amount of new issued will be

$$
\begin{aligned}
& \mathrm{mP}_{1}= \mathrm{I}-\left[\mathrm{E}-\mathrm{nD}_{1}\right] \\
& \text { or, } \\
& \mathrm{mP}_{1}=\mathrm{I}-\mathrm{E}+\mathrm{nD}_{1}
\end{aligned}
$$

\section{Step-5}

By substituting the value of $\mathrm{mP}$ from equation (4) to equation (3), we get

$$
\begin{aligned}
& \begin{array}{c}
\mathrm{nP}_{\mathrm{o}}=\frac{\mathrm{nD}_{1}+\mathrm{P}_{1}(\mathrm{n}+\mathrm{m})-\mathrm{I}+\mathrm{E}-\mathrm{nD}_{1}}{1+\mathrm{K}_{\mathrm{e}}} \\
\mathrm{Or},
\end{array} \\
& \mathrm{nP}_{\mathrm{o}}=\frac{\mathrm{nD}_{1}+\mathrm{nP}_{1}+\mathrm{mp}_{1}-\mathrm{I}+\mathrm{E}-\mathrm{nD}_{1}}{1+\mathrm{K}_{\mathrm{e}}} \\
& \text { Or, } \\
& \mathrm{nP}_{\mathrm{o}}=\frac{\mathrm{P}_{1}(\mathrm{n}+\mathrm{m})-\mathrm{I}+\mathrm{E}}{1+\mathrm{K}_{\mathrm{e}}}
\end{aligned}
$$

By solving the above equation, the value of firm does not change after declaring the dividend $i$. e. there is not any effect on dividend policy on the total value of firm.

Source: (R.M. Dangol)

\section{Mathematical application}

A textile company belongs to a risk-class for which the cost of equity is $10 \%$. It has 50000 outstanding shares selling at Rs. 100 each. The firm is contemplating the declaration of Rs. 8 dividend at the end of the current fiscal year, which has just started. Assuming that $\cong$ the firm pays the dividend, has net income $\rightarrow$ of Rs. 500,000 and makes new investment o $\dot{z}$ Rs. 10,00,00o during the period. It shows that under the M-M assumptions the payment of dividend does not affect the value of firm.

Solution:

Here, cost of equity $\left(\mathrm{K}_{\mathrm{e}}\right)=\frac{10}{100}=0.1$

No. of shares outstanding $(n)=50,000$ shares Market price per share $\left(\mathrm{P}_{\mathrm{o}}\right) \quad=$ Rs. 100
Expected dividend per share $\left(D_{1}\right)=$ Rs. 8 Amount of New investment (I) = Rs. 10,00,000 Net income (E) = Rs. 5,00,000

Calculation of the value of the firm assuming the firm pays dividend by using following stepss.

\section{Step-1}

Calculation of price per share at the end of the year

$$
\begin{aligned}
\therefore \mathrm{P}_{1} & =\mathrm{P}_{\mathrm{o}}\left(1+\mathrm{K}_{\mathrm{e}}\right)-\mathrm{D}_{1} \\
& =100(1+0.1)-\text { Rs. } 8 \\
& =\text { Rs. } 110-8 \\
& =\text { Rs. } 110-8 \\
& =\text { Rs. } 102
\end{aligned}
$$

\section{Step-2}

Calculation of price per share at the end of the year

$$
\begin{aligned}
\therefore \mathrm{M} & =\frac{\mathrm{I}-\left[\mathrm{E}-\mathrm{n}_{1} \mathrm{D}_{1)}\right.}{\mathrm{p}_{1}} \\
& =\frac{10,00,000-[500,000-50,000 \times 8]}{102} \\
& =\frac{9,00,000}{102} \\
& =, 823.53 \cong 8,824 \text { shares }
\end{aligned}
$$

\section{Step-3}

Calculation of value of the firm

$\mathrm{nP}_{\mathrm{o}}=\frac{\mathrm{P}_{1}(\mathrm{n}+\mathrm{m})-\mathrm{I}+\mathrm{E}}{1+\mathrm{K}_{\mathrm{e}}}$

$=\frac{102[50,000 / 102+9,00,000]-10,00,000+5,00,000}{1+0.1}$

$=\frac{192 \times \frac{6,00,000}{102}-5,00,000}{1.1}$

$=$ Rs. 50,00,00

Thus, value of the firm Rs. 50,00,000 if the firm pays dividend

Calculation of value of the firm assuming the firm does not pay dividend by using following steps. 


\section{Step-1}

Calculation of price of share at the end of the year

$$
\begin{aligned}
\mathrm{P}_{1} & =\mathrm{P}_{\mathrm{o}}\left(1+\mathrm{K}_{\mathrm{e}}\right)-\mathrm{D}_{1} \\
& =100(1+0.1)-\text { Rs. } \mathrm{O} \\
& =\text { Rs. } 110-\mathrm{o} \\
& =\text { Rs. } 110
\end{aligned}
$$

\section{Step-2}

Calculation of new number of shares to be issued

$$
\begin{aligned}
& \mathrm{M}=\frac{\mathrm{I}-\left[\mathrm{E}-\mathrm{nD}_{1}\right]}{\mathrm{P}_{1}} \\
& =\frac{10,00,000-[5,00,000-50,000]}{110} \\
& =\frac{10,00,000-5,00,000+0}{110} \\
& =\frac{5,00,000}{110} \\
& =4545.45 \cong 4545 \text { shares }
\end{aligned}
$$

\section{Step-3}

Calculation of value of the firm

$$
\begin{aligned}
\mathrm{nP}_{\mathrm{o}} & =\begin{array}{c}
\mathrm{P}_{1}(\mathrm{n}+\mathrm{m})-\mathrm{I}+\mathrm{E} \\
1+\mathrm{K}_{\mathrm{e}}
\end{array} \\
& =\frac{\operatorname{Rs} .110 \times(50,000 / 110+50000)-1,00,000+5,00,000}{1.1} \\
& =\frac{\text { Rs. } 110 \times \frac{60,00,000}{116-5,00,000}}{1.1} \\
& =\frac{55,00,000}{1.1} \\
& =\text { Rs. 50,00,000 }
\end{aligned}
$$

Thus, Value of the firm is Rs 5o, oo, ooo if the firm does not pay dividend as shown by above computation under the MM assumption the payment of dividend does not affect the value of the firm. In both the cases above, the value of the firm is same i.e. Rs 50,00,000.

\section{Conclusion}

Since dividend does not appear directly in expression and $\mathrm{E}, \mathrm{I},(\mathrm{n}+\mathrm{m}), \mathrm{P}_{1}$ and $\mathrm{K}_{\mathrm{e}}$ are assumed to be independent of dividend. In other words, M-M concludes that dividend policy is irrelevant and dividend policy has no effect in the value of the firm. A firm that pays dividend will have to raise funds externally to finance its investment plans. M-M hold that when the firm pays dividend external financing offers its advantage.

Its does not seem so relevant to apply MM approach in Nepalese context because when we apply this approach, the assumption supported by MM are significantly deviated. In Nepal, we are unable to find the rational investors as well as perfect capital market, which are considered my MM. I does not seem so round to neglect the floatation cost, transaction cost and tax effect on capital gain as neglected by MM. Arbitrage arguments are explain by MM applies only when there are very sensitive investors and they are lacking in Nepal. In conclusion we can say that MM theory is appropriated when there is absence of tax \& floatation cost.

\section{References}

Dangol, Ratna M.(2052 BS). Financial management theory and practice (3rd ed.). Kathmandu: Taleju Prakashan.

Khan, M.Y. and Jain, P.K.(1992). Financial Management Text and problems ( $\left.2^{\text {nd }} e d.\right)$. New Delhi: TaTa Mc Graw Hill Publishing Company Ltd.

Miller, Morton H. and Modigliani( 1961). Dividend policy, Growth and valuation of the shares Journal of Business, XXIV, PP411-433.

Pradhan, S.(2000). Basics of financial management ( $2^{\text {nd }}$ ed.). KathmanduL: Educational Enterprises. 